\title{
Correlation of Nitric Oxide (NO) and Corticotrophin Releasing Hormone (CRH) between Normal Pregnancy and Preeclampsia
}

\author{
Muhammad Alamsyah Aziz ${ }^{*}$, Sofie Rifayani Krisnadi ${ }^{2}$, Jusuf S. Effendi ${ }^{1}$, Johanes C. Mose ${ }^{1}$, \\ Riesa K. W. Rohmat ${ }^{1}$ \\ ${ }^{1}$ Department of Obstetrics and Gynecology, Faculty of Medicine, Hasan Sadikin Hospital/University of Padjadjaran, Bandung, Indonesia \\ ${ }^{2}$ Reproductive Health Study Center, Universitas Padjadjaran, Bandung, Indonesia \\ Email: *alamsyahaziz9119@gmail.com
}

How to cite this paper: Aziz, M.A., Krisnadi, S.R., Effendi, J.S., Mose, J.C. and Rohmat, R.K.W. (2016) Correlation of Nitric Oxide (NO) and Corticotrophin Releasing Hormone (CRH) between Normal Pregnancy and Preeclampsia. Open Journal of Obstetrics and Gynecology, 6, 807-817. http://dx.doi.org/10.4236/ojog.2016.613099

Received: October 6, 2016

Accepted: December 3, 2016

Published: December 6, 2016

Copyright $\odot 2016$ by authors and Scientific Research Publishing Inc. This work is licensed under the Creative Commons Attribution International License (CC BY 4.0).

http://creativecommons.org/licenses/by/4.0/ (c) (i) Open Access

\begin{abstract}
Preeclampsia is still a major cause of maternal death in pregnancy which needs efforts to prevent and early detection. Nitric oxide and Corticotrophin Releasing Hormone has an important role in the pathogenesis of preeclampsia to determine differences in concentrations of $\mathrm{NO}$ and $\mathrm{CRH}$ in normal pregnancy and preeclampsia, as well as to study the correlation both on the incidence of preeclampsia. This is a cross sectional study. Blood samples obtained from patients with preeclampsia (30 samples) and normal pregnancies as controls (30 samples) in accordance with inclusion and exclusion criteria. NO concentration was examined with essay protocol, and CRH concentrations with ELISA method. Then be calculated by statistical analysis: chi square, $t$ test, Mann-Whitney, and Spearman Rank correlation coefficient. Based on statistical analysis, there was no significant difference $(p>0.05)$ from the characteristics of maternal age, pregnancy weeks, and parity in both study groups, so the two groups of homogeneous and comparable. The mean concentration of NO in preeclampsia was lower $(3.780 \mu \mathrm{M})$ compared with normal pregnancy $(13.360 \mu \mathrm{M})$. There was significant correlation between $\mathrm{NO}$ and $\mathrm{CRH}$ concentrations in normal pregnancy and preeclampsia $(\mathrm{p}<0.001)$. The involvement of NO/c-GMP pathway is very possible in the pathogenesis of preeclampsia.
\end{abstract}

\section{Keywords}

Preeclampsia, Normal Pregnancy, NO, CRH, NO/c-GMP Pathway

\section{Introduction}

Pregnancy-induced Hypertension (PIH) is one of the most prevalent complications of 
pregnancy, delivery and post-partum that improve both maternal morbidity and mortality as well as perinatal [1] [2]. In 2001, according to data from the National Center for Health Statistics in USA, PIH occurs in 150,000 women, or 3.7\% of all pregnancies. The study reported a nearly $16 \%$ from 3201 pregnancies that resulted in the deaths caused by hypertension in pregnancy [1]. PIH happened about $6 \%-10 \%$ of all pregnancies based on WHO data in 2011 [3]. Iihara et al., suggests an increase in the incidence of maternal death caused by preeclampsia was approximately $83 \%$ in the period 2006-2007 [4]. Deaths in cases of preeclampsia increases with increasing degrees of disease severity and complications caused by preeclampsia.3Household Health Survey in Indonesia stated preeclampsia remains one contributor to primary maternal mortality. The incidence of preeclampsia in Indonesia is about $3.4 \%$ to $8.5 \%$ of all pregnancies. The maternal mortality rate that associated with severe preeclampsia/eclampsia reached $9.8 \%$ to $25 \%$ [5]. Incidence of severe preeclampsia in West Java was collected from 12 hospitals period 1996 to 1997 ranged from $0.8 \%$ to $14.1 \%$. The incidence of PIH in Dr. Hasan Sadikin Hospital between 1991-1994 period was recorded from 7.9\% to $8.9 \%$ consists of $2.8 \%$ to $5.8 \%$ of severe preeclampsia and eclampsia $0.6 \%$ to $1.9 \%$, whereas in 1996-1997 preeclampsia reached 5.8\% and 0.6\% for eclampsia [6]. During the period of 2000-2003, at the Dr. Hasan Sadikin Hospital, the incidence of slight preeclampsia ranges between $4.0 \%-8.0 \%$, while severe preeclampsia was $8.7 \%-11.0 \%$. In 2003 and 2006, the incidence of preeclampsia ranges from $3.0 \%$ to $7.37 \%$ and eclampsia of $1.3 \%-3.5 \%$ [7] [8] [9] [10].

In recent decades found no significant preeclampsia reduction, which means, even in developed countries, these complications are still causes many considerable morbidity and mortality for both mother and fetus [1] [2] [6] [11] [12]. Therefore, good management with strict monitoring of the condition of the mother and the fetus is very important in order to prevent the development of preeclampsia to be more severe and happened to be endangering the lives of the mother and fetus. Many pregnant women who come to the hospital for complications of hypertension stage even worse as severe preeclampsia syndrome Hemolysis, Elevated Liver enzymes, Low Platelets count (HELLP) or eclampsia [13] [14] [15], didn't find satisfactory result. The prevention and intervention of this disease will provide better results if they can be treated as early as possible [16]. The role of antenatal care for earlydetection of preeclampsia is screening for preeclampsia risk group. Decker and Sibai (1991) divided the early detection of preeclampsia into 5 major categories: a standard examination on antenatal care, hematology examination, vascular system examination, biochemical examination, and ultrasonography examination. The ideal examination is simple, easy to do, inexpensive, quick, non-invasive, and has the highest accuracy [17].

Prediction and early detection of preeclampsia can be pursued by examining the biochemical and biophysical markers which are mainly based on his involvement in the pathology and pathophysiology PIH. The researchers sought to identify markers of early placentation disorders, decreased placental perfusion, endothelial cell dysfunction, and activation coagulation [1]. Research in recent years has shown that endothelial damage is pathogenesis agent for preeclampsia [1] [11] [18]. 
Many researchers put forward theories about preeclampsia. The theory most often discussed begins with endothelial damage which would stimulate the activity of platelets to perform adhesion, aggregation and release reaction [19] [20]. This event will end with decreasing levels of vasodilator substances such as prostacyclin and nitric oxide (NO), otherwise known as endothelium derived relaxing factor and increased vasoconstrictor substances such as thromboxane and endothelia [21]. More dominant vasoconstrictor factors will cause vasospasm specially blood vessels [1] [22] [23]. Vasoconstriction will then stimulate spending renin and angiotensin. This expenditure will increase the mass of vasoconstriction caused hypertension, increased capillary permeability and fluid retention resulting in edema and proteinuria [24] [25] [26] [27].

The discovery of endothelium derived relaxing factor, which became known as NO is the most exciting discovery and has long been discussed in medical science since the 1980s. NO plays a role in inhibiting the inflammatory process. NO is a relaxant substances from the endothelium, NO was first attested by Furchgott and Zawadski. NO is synthesized from L-Arginine, with the influence of the enzyme NO-synthase (NOS). There are three forms of NOS isoforms namely: brain NOS (bNOS) or neuronal NOS (nnos or NOS 1), endothelial NOS (eNOS or NOS3) and inducible NOS (iNOS or NOS 2) [28] [29] [30]. Therefore not strange if NO nominated in science as the "molecule of the year" in 1992, and its discovery was also awarded the Nobel Prize in 1998. NO is a gas molecule which is highly reactive free radicals with a very short half-life. This molecule is known as a mediator in many biological processes, including smooth muscle relaxation, immune and inflammation [31] [32]. NO is involved in almost all areas of bio-regulation and medical [22].

Another theory states that preeclampsia occurs because the inflammatory cascade, which causes the release of a variety of peptides by the placenta and some of the peptide can be a marker for predicting the incidence of preeclampsia, the peptide include the corticotrophin releasing hormone ( $\mathrm{CRH}$ ), chorionic gonadotropin, Activin A and Inhibin A [1] [33]. CRH is synthesized and released by the hypothalamus in response to stress. CRH is also synthesized in the human placenta and fetal membranes during pregnancy. CRH levels in plasma were not detected in non-pregnant adult women, while in pregnancy $\mathrm{CRH}$ derived from the placenta appears well on maternal and fetal circulation. Good CRH in maternal and fetal plasma disappears from the plasma within 24 hours after gave birth [34]. CRH is a potential vasodilator in human fetoplacental circulation and function in regulating vascular tone, activation via Nitric oxide/c-GMPme-diated pathway. Levels of CRH high will affect vasodilation of blood vessels and leads to reduced CRH-receptor (CRH-R) The role of CRH as a marker that can be used to predict the incidence of preeclampsia until now there has not been much studied, most research on CRH in pregnancy aimed to investigate the relationship between the $\mathrm{CRH}$ levels with the incidence of prematurity and delay of fetal growth [34]. Therefore, the authors feel compelled to do some research to compare the levels of NO and CRH in normal pregnancy and pre-eclampsia and to know is there any correlation to the possibility of the occurrence of preeclampsia due to endothelial damage which ended 
with decreased levels of $\mathrm{NO}$ and $\mathrm{CRH}$ levels rise in maternal plasma.

The results of this study are expected to be able to obtain information useful for scientific development by contributing an understanding of the influence of inflammation and decreased vasodilator substance that will lead to increased levels of CRH by assess the levels of $\mathrm{NO}$ and $\mathrm{CRH}$ difference between normal pregnancy with preeclampsia. Besides trying to find a good screening connecting it with the incidence of preeclampsia seen from the NO/c-GMP, as well as a decrease in the inflammatory process vasodilator substances by measuring the levels of NO and CRH relationship between normal pregnancies with preeclampsia.

\section{Experimental}

Every pregnant woman who meets the inclusion and exclusion criteria, prior to entering the study, the patient/family to get a detailed explanation of the research procedures and voluntarily signed the sheet statement to join the study. In this study, subjects study examined the levels of $\mathrm{NO}$ and $\mathrm{CRH}$ by taking a blood sample as much as $6 \mathrm{cc}$ examination materials. Examination materials sent to the laboratory for examination levels of NO and $\mathrm{CRH}$. The results were analyzed statistically.

\subsection{NO Examination Techniques}

\section{Sampling}

Take $3 \mathrm{cc}$ blood sample, put in $5 \mathrm{cc}$ plain tubes, let stand 30 - 45 minutes. Centrifuged at $3000 \mathrm{rpm} 15$ minutes right after. Immediately separate serum insert into the 2 sample cup $0.5 \mathrm{cc}$ of serum each, give an identity to the tube and store in $-20^{\circ} \mathrm{C}$ immediately.

\subsection{Laboratory Tests NO (Assay Procedure)}

Add $200 \mu \mathrm{l}$ water or Assay Buffer into the empty plate. Do not enter any other Reagents into the plate. Add up to $80 \mu \mathrm{L}$ of sample or diluted sample into the plate. The final volume should be set at $80 \mu$ using the assay buffer solution. Note: Plasma samples should not be more than $40 \mu \mathrm{L}$ when using undiluted samples (samples diluted 1:2 or more can be used up to $80 \mu \mathrm{L}$ ). Pipette the sample carefully to make sure there are no air bubbles get into the plate (bubbles can cause error results). Add $10 \mu \mathrm{L}$ enzyme cofactor mixture into each plate.

Add $10 \mu \mathrm{L}$ of a mixture of nitrate reductase into each plate. Cover plate with lid and at room temperature for 1 hour. (Note: The incubation time must be increased to 2 hours when conducted assay in tissue culture media, and made 3 hours when performed on plasma or nitrate + nitrite tissue). No need to shake the plate during incubation. After incubation is complete, add $50 \mu \mathrm{L}$ of Griess Reagent R1 (Catalog No. 780 018) into each container. Immediately add $50 \mu \mathrm{L}$ ReagentGriess $\mathrm{R} 2$ into each container. Let the color changes for 10 minutes at room temperature. No need to close the plate. Note: The optimal incubation for 10 minutes for the appearance of color. However, if the plate is leaved more than 10 minutes the result will remain valid. Read absorbance at $540 \mathrm{~nm}$ or $550 \mathrm{~nm}$ using a plate reader. 


\subsection{CRH Examination Techniques}

\section{Sampling}

Take 3 cc sample of blood into 3 cc EDTA tube then flip the tube gently until homogenous. Immediately insert 300 uLaprotinin, flip tube until homogeneous. Centrifuge the tube at $1600 \mathrm{~g}$ for $15 \mathrm{~min}, 4^{\circ} \mathrm{C}$. Immediately separate the plasma insert into the 2 sample cup $1.2 \mathrm{cc}$ plasma each. Give the identity and the type of inspection store at $-20^{\circ} \mathrm{C} /-70^{\circ} \mathrm{C}$.

\subsection{Extraction of Peptides from Plasma}

Acidify plasma with buffer A (ELISA) by the same amount. For example, if you use 1 $\mathrm{ml}$ plasma, add $1 \mathrm{ml}$ of buffer $\mathrm{A}$. Mix and centrifuge at a speed of 6000 to $17,000 \times \mathrm{g}$ for 20 minutes of $4^{\circ} \mathrm{C}$. Equilibrate SEP-COLUMN consisting of $200 \mathrm{mg}$ of C18 (Cat. No. RK-SEPCOL-1) by washing with buffer B ( $1 \mathrm{ml}$, once) followed by buffer A ( $3 \mathrm{ml}, 3$ times). Note: steps 3 - 5, there should be no pressure. The contents of plasma that has been acidified solution to the pre-equilibrated C-18 SEP Column. Wash gently with buffer A ( $3 \mathrm{ml}, 2$ times) and remove the washers. Slowly elute peptide with buffer B (3 $\mathrm{ml}, 1$ time) and enter eluent into polystyrene tubes. Eluent is evaporated to dryness in a centrifugal concentrator or using the appropriate substitution. Keep the extract dry in $-20^{\circ} \mathrm{C}$ and perform the ELISA as soon as possible. Use the assay buffer 1 time for reconstituting the dried extract. If the number of peptides can't be detected, perform the appropriate dilution or concentration.

\subsection{Techniques for Extraction of Plasma}

When using a C-18 SEP COLUMN for the first time, use the pressure to the column after the addition of $1 \mathrm{ml}$ of buffer B to facilitate the flow through the column. Make sure there is a constant flow on all the solution during the extraction process. There should be no air bubbles into the sample C-18 for the optimal sample processing.

\subsection{Drying the Sample after Extraction}

The combination of centrifugal concentrators (e.g: Speedvac) and lyophilizer (freeze dryer) gives the best results in the drying process the samples after extraction. First, use Speedvac to dry the samples for about 15 minutes to remove the organic layer. Then freeze the rest of the sample, and freeze-dried one night using a lyophilizer. The second step is to produce a fine powder that is more consistent that it will be easier to sample than just rehydrated dried using a centrifugal concentrator. However, if there is no centrifugal concentrator, freeze drying one night can still be done.

\subsection{Data Analysis}

Data were analyzed by statistical test, to compare the characteristics between the two study groups used the chi square test for categorical data, $t$ test to compare the differences in the two middle values of the levels of $\mathrm{NO}$ and $\mathrm{CRH}$ if normally distributed data or the Mann-Whitney test if the data are not normally distributed. To assess the rela- 
tionship between the levels of NO and CRH used Spearman rank correlation analysis. The significance of test results is determined by the value of $\mathrm{p}<0.05$.

\section{Result}

Research on the relationship between the levels of NO and CRH normal pregnancies with preeclampsia have been conducted during the period March to May 2010. During this period obtained sample of 30 pregnant women as a control group and 30 women with preeclampsia. The whole subject of research conducted and CRH levels of NO votes. Characteristics of research subjects by age, parity and gestational age in normal pregnancy and preeclampsia can be explained in Table 1 below.

According to the table above shows that the statistical analysis with $95 \%$ confidence level indicates that there is no age difference between the two study groups $\mathrm{p}=0.514$ ( $p$-value $>0.05$ ), there is no difference between the study arms parity with the value of $\mathrm{p}=0.746$ (the value of $\mathrm{p}>0.05$ ), and there are no differences in pregnancy weeks in both groups with $p=0.608(p>0.05)$. Based on the statistical test results can be seen that the characteristics of the study subjects according to age, parity and pregnancy weeks between the two study groups are homogeneous so that it can be analyzed further.

Table 2 shows that the average levels of NO in the study subjects who develop preeclampsia lower than normal pregnancy is $3.780 \mu \mathrm{M}$ the standard deviation 1.209 median 3.708. While the average levels of NO in the study subjects with normal pregnancies is $13.360 \mu \mathrm{M}$ with a standard deviation 5.237, median 12.768, and MannWhitney test analysis results at the $95 \%$ confidence level indicates that there are differences in the levels of $\mathrm{NO}$ were significantly between the control group and preeclampsia with a value of $\mathrm{p}=0.001(\mathrm{p}<0.05)$.

Table 1. Characteristics of subjects research by age, parity and pregnancy weeks in normal pregnancy and preeclampsia.

\begin{tabular}{cccc}
\hline & \multicolumn{2}{c}{ Group of Research } & \\
\cline { 2 - 3 } Characteristic & Statistical Analysis \\
\cline { 2 - 2 } Age (yr) & $3(10.0 \%)$ & $3(10.0 \%)$ & \\
$<20$ & $13(43.3 \%)$ & $11(36.7 \%)$ & \\
$20-24$ & $9(30.0 \%)$ & $10(33.3 \%)$ & $\mathrm{t}=0.656$ \\
$25-29$ & $3(10.0 \%)$ & $4(13.3 \%)$ & $\mathrm{p}=0.514$ \\
$30-34$ & $2(6.7 \%)$ & $2(6.7 \%)$ & \\
$35-40$ & $25.13(5.10)$ & $26.03(5.51)$ & \\
Mean $( \pm$ SD) & $16-37$ & $18-38$ & \\
Range & & & \\
Parity & $15(50.0 \%)$ & $14(46.7 \%)$ & $\mathrm{z}=0.746$ \\
0 & $15(50.0 \%)$ & $16(53.3 \%)$ & \\
$1-3$ & & & \\
Pregnancy (weeks) & $9(30.0 \%)$ & $8(26.7 \%)$ & $\mathrm{t}=0.515$ \\
$20-27$ & $15(50.0 \%)$ & $13(43.3 \%)$ & $\mathrm{p}=0.608$ \\
$28-36$ & $6(20.0 \%)$ & $9(30.0 \%)$ & \\
$>37$ & $31.8(4.6)$ & $32.4(5.4)$ & \\
Mean $( \pm$ SD) & $24-38$ & $22-40$ & \\
Range & & &
\end{tabular}

Note: $\chi^{2}=$ chi square; $\mathrm{t}=t$ test; $\mathrm{p}$ value based on $\mathrm{p} \leq 0.05$ significancy. 
Table 2. Comparison of NO levels between the group preeclampsia with control group.

\begin{tabular}{ccccc}
\hline \multirow{2}{*}{ NO Levels $(\mu \mathrm{M})$} & \multicolumn{2}{c}{ Group of Research } & \multirow{2}{*}{$\mathrm{Z}_{\mathrm{M}-\mathrm{w}}$} & P value \\
\cline { 2 - 3 } & Preeclampsia $(\mathrm{n}=30)$ & Normal $(\mathrm{n}=30)$ & & \\
\hline Mean(SD) & $3.780(1.209)$ & $13.360(5.237)$ & -6.655 & $<0.001$ \\
Median & 3.708 & 12.768 & & \\
Range & $2-7.26$ & $9.28-28.31$ & \\
\hline
\end{tabular}

Note: $\mathrm{Z}_{\mathrm{M}-\mathrm{W}}$ (Mann-Whitney test).

Here described the relation between the levels of NO and CRH between normal pregnancies with preeclampsia in Table 3.

From the above table it is known that there is a significant correlation between the levels of NO and CRH both in normal pregnancy and preeclampsia $\mathrm{p}=0.001$ ( $\mathrm{p}<$ 0.05). With a value of negative correlation means that the lower the levels of NO, the higher the levels of $\mathrm{CRH}$ or otherwise.

\section{Discussion}

\subsection{Characteristics of Research Subjects}

Sixty research subjects consisted of 30 subjects in the group of preeclampsia and 30 others in a group of normal pregnancy. Characteristics of research subjects in both groups there was no significant difference of age, parity and pregnancy weeks.

Various studies on the effect of maternal age and parity on the occurrence of preeclampsia often mentioned, it is mentioned that young age had a greater risk to preeclampsia. [1] [2] In this study between a control group and preeclampsia homogeneous with $\mathrm{p}>0.05$. After statistical analysis and matching with a view to obtaining homogeneous samples as in Table 1 to the two groups based on the characteristics of maternal age, parity and pregnancy weeks. The test results $\mathrm{x}^{2}$ (squared test) and test with a confidence level of $95 \%$ for maternal characteristics $p$ value $<0.05$ in both study groups respectively: maternal age $\mathrm{p}=0.514$; parity $\mathrm{p}=0.746$ and $\mathrm{p}=0.608$ pregnancy, so it concluded there was no significant difference between the study arms and that both groups can be compared.

\subsection{Comparison between the Levels of NO and CRH Normal Pregnancy and Preeclampsia}

It is known that the average levels of NO in the study subjects who develop preeclampsia lower than normal pregnancy is $3.780 \mu \mathrm{M}$ with a standard deviation of 1,209 median of 3.708 while the average levels of NO in the study subjects with normal pregnancy is $13.360 \mu \mathrm{M}$ with a standard deviation of 5.237 median 12.768 and analytical results Mann Whitney at $95 \%$ confidence level indicates that there are differences in the levels of NO were significantly between the control group and preeclampsia with a value of $\mathrm{p}=$ $0.001(\mathrm{p}<0.05)$ (Figure 1).

Decreased levels of NO in preeclampsia is possible because there has been damage 
Table 3. Relationship between the levels of $\mathrm{NO}$ and $\mathrm{CRH}$ normal pregnancy and preeclampsia.

\begin{tabular}{ccccccc}
\hline \multirow{2}{*}{ Relation } & \multicolumn{2}{c}{ Preeclamsia } & \multicolumn{2}{c}{ Normal Pregnancy } & \multicolumn{2}{c}{ Combined Data } \\
\cline { 2 - 7 } & $\mathrm{r}_{\mathrm{s}}$ & Nilai $\mathrm{p}$ & $\mathrm{r}_{\mathrm{s}}$ & Nilai $\mathrm{p}$ & $\mathrm{r}_{\mathrm{s}}$ & Nilai $\mathrm{p}$ \\
\hline CRH and NO & 0.042 & 0.827 & -0.258 & 0.169 & -0.778 & $<0.001$ \\
\hline
\end{tabular}

Note: $r_{s}=$ correlation coefficient Rank-Spearman.

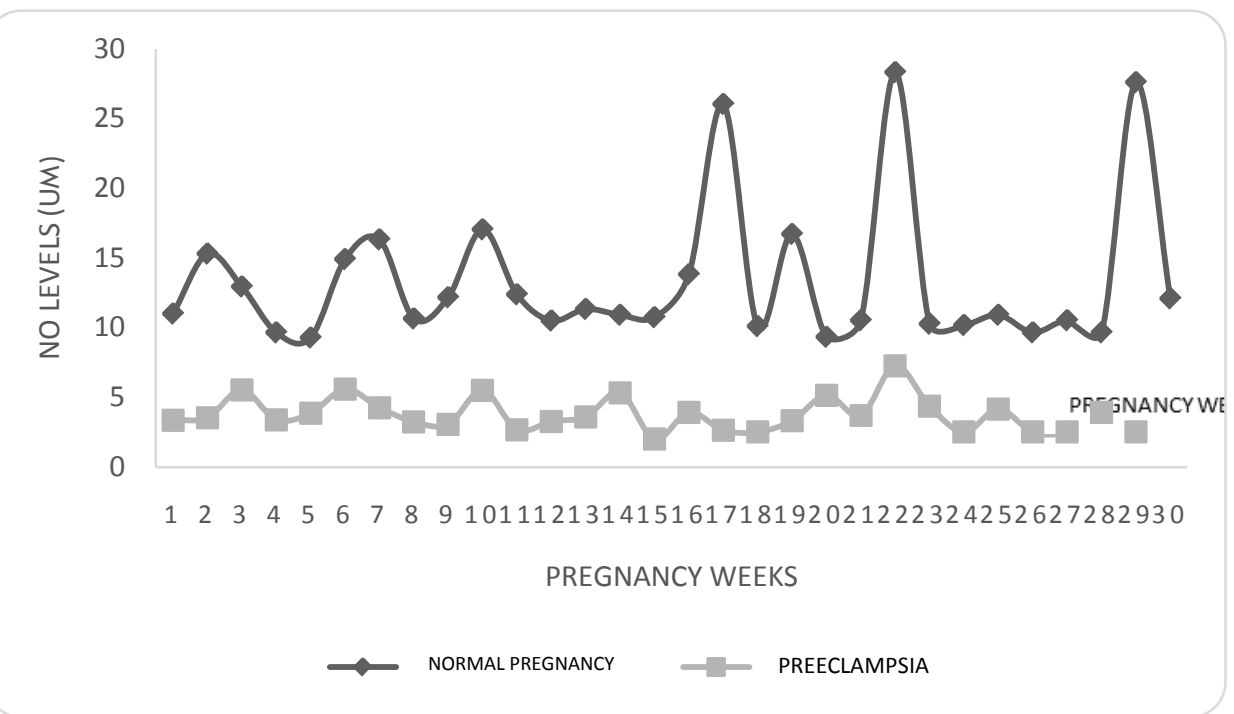

Figure 1. Comparison of NO levels between normal pregnancy and preeclampsia.

endothelium, inflammatory process that continues to cause the release of renin-angiotensin in blood vessels continues with vasoconstriction of blood vessels. Research by Buschimsiet al, which causes the inhibition of NO synthesis in rats that pregnant will cause a state resembling preeclampsia [35] Figure 2.

The mean levels of CRH in research subjects who develop preeclampsia is higher than the normal pregnancy is $21.164 \mathrm{ng} / \mathrm{mL}$ with a standard deviation of 25.759 and median 17.672, while the average levels of CRH in research subjects with normal pregnancy is $0.972 \mathrm{ng} / \mathrm{mL}$ with a standard deviation of 0.925 and median 0.545 and analytical results Mann Whitney test at 95\% confidence level showed that there are significant differences in levels of CRH between the control group and preeclampsia with a value of $\mathrm{p}=0.001(\mathrm{p}<0.05)$. The value obtained is still higher when compared with the another research [1] [34] [36] [37].

\subsection{The Relationship between the Levels of NO and CRH Normal Pregnancy and Preeclampsia}

From the tables above is known that there was significant relationship between the levels of NO and CRH both in normal pregnancy and preeclampsia $\mathrm{p}=0.001(\mathrm{p}<0.05)$. The relationship between the levels of $\mathrm{NO}$ and $\mathrm{CRH}$ is important to observe, the state of vasoconstriction caused by a decrease in vasodilator substance that can activates the renin-angiotensin system which will affect the syncytiotrophoblast produces CRH so 


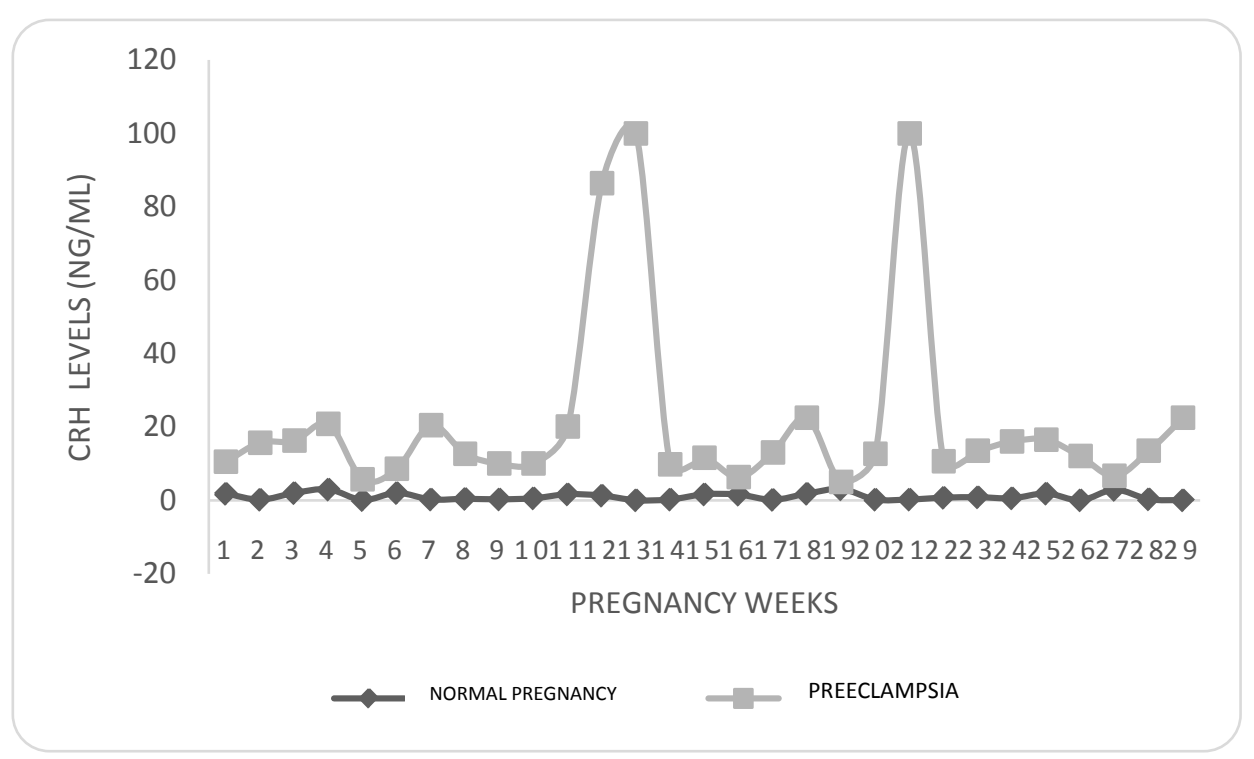

Figure 2. Comparison CRH levels between normal pregnancy and preeclampsia.

that the release of $\mathrm{CRH}$ in the maternal circulation will increase this also will cause a decrease in the number of receptors $\mathrm{CRH}$, which will affect the path of NO/c-GMP so the role of $\mathrm{CRH}$ as vasodilator forblood vessels to be able to create a state of balance between vasoconstrictor and vasodilator substances. Besides the inflammatory process and stress play a role in influencing this situation. NO pathway/c-GMP very important role to maintain this balance.

\section{Conclusion}

There are significant differences in NO levels between normal pregnancy and preeclampsia higher in normal pregnancy and lower in preeclampsia and significant differences between the levels of CRH normal pregnancy and preeclampsia lower in normal pregnancy and higher in preeclampsia. There is a significant negative correlation between the levels of $\mathrm{NO}$ and $\mathrm{CRH}$ normal pregnancy and preeclampsia.

\section{References}

[1] Cunningham, F.G., Norman, F.G., Kenneth, J.L., Larry, C.G., John, C.H. and Katharine, D.W. (2005) Williams Obstetrics. 22 Edition, Williams and Wilkins, New York.

[2] Hallak, M. Hypertension in Pregnancy. In: James, D.K., Weiner, C.P. and Gonik, B., Eds., High Risk Pregnancy Management Option, 2nd Edition, WB Saunders, London, 639-663.

[3] World Health Organization (2011) WHO Recommendations for Prevention and Treatment of Preeclampsia and Ecplampsia.

[4] Iihara, K. and Nishimura, A. (2015) Maternal Death Due to Stroke Associated with Pregnancy-Induced Hypertension. Circulation Journal, 79, 1695-1969. http://dx.doi.org/10.1253/circj.CJ-15-0701

[5] Saifudin, A.B. (Ed.) (2000) National Reference Book Maternal and Neonatal Health Services. Bina Pustaka Sarwono Prawirohardjo Foundation, Jakarta. 
[6] Greer, I.A. (2002) Pregnancy Induced Hypertension. In: Chamberlain, G. and Steerp, P.J., Eds., TurnbulP s Obstetrics, 3rd Edition, Churchill Livingstone, London, 333-350.

[7] Obstetrics and Gynecology, Faculty of Medicine (2004) Annual Report 2003. Obstetrics and Gynecology, Faculty of Medicine, University of Padjadjaran, Hasan Sadikin Hospital, Bandung.

[8] Obstetrics and Gynecology, Faculty of Medicine (2005) Annual Report 2004. Obstetrics and Gynecology, Faculty of Medicine, University of Padjadjaran, Hasan Sadikin Hospital, Bandung.

[9] Obstetrics and Gynecology, Faculty of Medicine (2006) Annual Report 2005. Obstetrics and Gynecology, Faculty of Medicine, University of Padjadjaran, Hasan Sadikin Hospital, Bandung.

[10] Obstetrics and Gynecology, Faculty of Medicine (2007) Annual Report 2006. Obstetrics and Gynecology, Faculty of Medicine, University of Padjadjaran, Hasan Sadikin Hospital, Bandung.

[11] Creasy, R.K. and Resnik, R. (2004) Maternal Fetal Medicine Principles and Practice. 3rd Edition, WB Saunders, London.

[12] Reynolds, C., Mabie, W.C. and Sibai, B.M. (2003) Hypertensive States of Pregnancy. In: De Cherney, A.H., et al., Eds., Current Obstetric \& Gynecologic Diagnosis \& Treatment, 9th Edition, McGraw Hill, New York, 338-353.

[13] Boejang, R.F. (1991) Neonates of Maternal Preeclampsia and Eclampsia in RSCM, Seminars and Workshops Handling of Preeclampsia. RSCM, Jakarta.

[14] Hariyanto, W., Soeharso and Praptohardjo, U. (1994) Overview of Maternal and Perinatal Mortality Index Based Gestosis in Preeclampsia and Eclampsia, Collection of Papers KOGI IX. Jakarta.

[15] Sinaga, Y. (2003) Relations Maternal Risk Factors and Mode of Delivery in Patients with Preeclampsia/Eclampsia with Baby Output. KOGI XII, Yogyakarta.

[16] O'Brien, W.F. (1990) Early Detection of Preeclampsia. American Journal of Obstetrics \& Gynecology, 75, 445-452.

[17] Decker, G.A. and Sibai, B.M. (1991) Early Detection of Preeclampsia. American Journal of Obstetrics \& Gynecology, 161, 160-170. http://dx.doi.org/10.1016/0002-9378(91)90245-M

[18] Rodger, G.M. (1988) Hemostatic Properties of Normal and Pertubed Vascular Cells. FASEB Journal, 2, 116-123.

[19] Roberts, J. (2007) Pre-Eclampsia a Two Stage Disorder: What Is the Linkage? Are There Directed Fetal/ Placental Signals? In: Lyall, F. and Belfort, M., Eds., Preeclampsia: Etiology and Clinical Practice, Cambridge University Press, New York, 183-192.

[20] Wang, J. and Trodinger, B. (1998) Endothelial Cell Dysfunction in Preeclampsia. Journal of Nephrology, 11, 53.

[21] Rosselli, M., Imthurn, B., Macas, E., Keller, P.J. and Dubey, R.K. (1994) Endogenous Nitric Oxide Modulates Endothelin-1 Induced Contraction in Bovine Oviduct. Biochemical and Biophysical Research Communications, 201, 143-148. http://dx.doi.org/10.1006/bbrc.1994.1680

[22] Roberts, J.M., Taylor, R.N., Musci, T.J., Rodgers, G.M., Hubel, C.A. and Mclaughlin, M.K. (1989) Preeclampsia: An Endothelial Cell Disorder. American Journal of Obstetrics and Gynecology, 161, 1200-1204. http://dx.doi.org/10.1016/0002-9378(89)90665-0

[23] Folkman, J. and Shing, Y. (1992) Angiogenesis. Journal of Biological Chemistry, 267, 10931-10934. 
[24] DeGroot, C.J.M. (1995) The Role of Endothelial Cells in Preeclampsia. Krips Repro, Den Haag.

[25] Mose, J.C. (1999) Effect of Garlic Extract (Allium sativum) on Platelet Activity and Blood Pressure Pregnant Women at Risk for Preeclampsia. Padjadjaran University Graduate Program, Bandung.

[26] Dekker, G.A. and Sibai, B.M. (1997) Pathophysiology of Hypertensive Disorder. In: Gleicher, N., Gall, S.A., Sibai, B.M., Elkayam, U., Galbraith, R.M. and Sarto, G.E., Eds., Principles and Practice of Medical Therapy in Pregnancy, Appleton and Lange, New York, 845-852.

[27] Lyall, F. and Greer, A. (1996) The Vascular Endothelium in Normal Pregnancy and Preeclampsia. Reviews of Reproduction, 1, 107-116. http://dx.doi.org/10.1530/ror.0.0010107

[28] Marletta, M. (1994) Nitrikoksida Synthase: Aspects Concerning Structure and Catalysis. Cell, 78, 927-930. http://dx.doi.org/10.1016/0092-8674(94)90268-2

[29] Davidge, S.T., Baker, P.N., Laughlin, M.K. and Roberts, J.M. (1995) Nitric Oxide Produced by Endothelial Cells Increases Production of Eicosanoids through Activation of Prostaglandin H Synthase. Circulation Research, 77, 274-283. http://dx.doi.org/10.1161/01.RES.77.2.274

[30] Malamitsi-Puchner, A., et al. (2006) Investigation of Amniotic Fluid Factors as Potential Predictors of Term and Preterm Deliveries. Mediators of Inflammation, 2006, Article ID: 94381. http://dx.doi.org/10.1155/mi/2006/94381

[31] Furchgott, R.F. and Zawadzki, J.V. (1980) The Obligatory Role of Endothelial Cells in the Relaxation of Arterial Smooth Muscle by Acetylcholine. Nature, 288, 373-376. http://dx.doi.org/10.1038/288373a0

[32] Ignarro, L.J., Buga, G.M., Wood, K.S., Byrns, R.E. and Chaudhuri, G. (1987) EndotheliumDerived Relaxing Factor Produced and Released from Artery and Vein Is Nitric Oxide. Proceedings of the National Academy of Sciences of the United States of America, 84, 9265-9269. http://dx.doi.org/10.1073/pnas.84.24.9265

[33] Vitoratos, N., Papatheodorou, D.C., Kalantaridou, S.N. and Mastorakos, G. (2006) Reproductive Corticotrophin-Releasing Hormone. Annals of the New York Academy of Sciences, 1092, 310-318. http://dx.doi.org/10.1196/annals.1365.029

[34] Goland, R.S., Conwell, I.M. and Jozak, S. (1995) The Effect of Pre-Eclampsia on Human Placental Corticotrophin-Releasing Hormone Content and Processing. Placenta, 16, 375382. http://dx.doi.org/10.1016/0143-4004(95)90095-0

[35] Buhimschi, I., Yallampalli, C., Dong, Y.L. and Garfield, R.E. (1995) Involvement of the Mnitric-Cyclic Guanosine Monophosphate Pathway in Control of Human Uterine Contractility during Pregnancy. American Journal of Obstetrics and Gynecology, 172, 1577 1584. http://dx.doi.org/10.1016/0002-9378(95)90500-6

[36] Karteris, E., Grammatopoulos, D.K., Randeva, H.S. and Hillhouse, E.W. (2001) The Role of Corticotrophin-Releasing Hormone Receptors in Placenta and Fetal Membranes during Human Pregnancy. Molecular Genetics and Metabolism, 72, 287-296. http://dx.doi.org/10.1006/mgme.2001.3159

[37] Leung, T.N., Chung, T.K.H., Madsen, G., Lam, C.W.K., Lam, P.K.W. and Walters, W.A.W. (2000) Analysis of Corticotrophin-Releasing Hormone and $\alpha$-Fetoprotein Concentrations for Predicting Pre-Eclampsia. Human Reproduction, 15, 813-818. http://dx.doi.org/10.1093/humrep/15.8.1813 
Submit or recommend next manuscript to SCIRP and we will provide best service for you:

Accepting pre-submission inquiries through Email, Facebook, LinkedIn, Twitter, etc. A wide selection of journals (inclusive of 9 subjects, more than 200 journals)

Providing 24-hour high-quality service

User-friendly online submission system

Fair and swift peer-review system

Efficient typesetting and proofreading procedure

Display of the result of downloads and visits, as well as the number of cited articles

Maximum dissemination of your research work

Submit your manuscript at: http://papersubmission.scirp.org/

Or contact ojog@scirp.org 